\title{
Mastoidektomi Revisi pada Otitis Media Supuratif Kronik Tipe Bahaya
}

Jacky Munilson, Tuti Nelvia

\begin{abstract}
Abstrak
Operasi mastoid berkembang sebagai penanganan terhadap Otitis Media Supuratif Kronik (OMSK). Mastoidektomi revisi dilakukan bila tujuan operasi pertama tidak tercapai. Kegagalan operasi mastoid bisa disebabkan oleh berbagai hal, diantaranya penanganan air cell yang tidak adekuat, facial ridge yang tinggi, kegagalan membuang semua kolesteatom, meatoplasti yang tidak adekuat dan ketidakpatuhan pasien untuk kontrol setelah operasi. Operasi mastoid revisi biasanya lebih sulit dan berbahaya karena anatomi telinga tengah menjadi tidak jelas, landmark dapat hilang dan struktur berbahaya sudah terpapar. Dilaporkan satu kasus operasi mastoid revisi pada seorang laki-laki berumur 25 tahun, yang ditatalaksana dengan timpanomastoidektomi dinding runtuh.
\end{abstract}

Kata kunci: otitis media supuratif kronik, mastoidektomi revisi, kolesteatom, meatoplasti

\begin{abstract}
Surgery of the mastoid developed as a treatment for chronic suppurative otitis media. Revision mastoid surgery done if the aim of first surgery not achieved. Failure of mastoid operation may caused by many things, including handling of air cells are not adequate, high facial ridge, failure to remove all cholestetoma meatoplasty in adequate and non adherence of patient to control after surgery. Revision mastoid surgery is usually more difficult and dangerous, because anatomy of the middle ear may be altered, some of the important landmarks can be loss and dangerous structure has been exposed. It was reported one case revision mastoid surgery in a man aged 25 years old, management with canal wall down tympanomastoidectomy .
\end{abstract}

Keywords: chronic suppurative otitis media, revision mastoidectomy, cholesteatoma, meatoplasty

Affiliasi penulis: Bagian THT-KL Fakultas Kedokteran Unand Korespondensi: Jacky Munilson, E-mail :

jackymunilson@yahoo.co.id. Telp : 0751-37194

\section{PENDAHULUAN}

Otitis media supuratif kronik dengan kolesteatom adalah penyakit yang sering ditemukan, terutama di negara berkembang. Kolesteatom secarahistologis bersifat jinak, tetapi dapat bersifat destruktif secara lokal, yaitu dapat menyebabkan destruksi tulang dan menimbulkan komplikasi seperti meningitis, abses otak, labirintitis dan kelumpuhan saraf fasialis. ${ }^{1-3}$

Indikasi dilakukan mastoidektomi revisi adalah apabila tujuan operasi pertama tidak tercapai. Penyebab kegagalan operasi mastoid diantaranya penanganan air cell yang tidak adekuat, tidak berhasil membuang semua kolesteatom, facial ridge yang tinggi dan meatoplasti yang tidak adekuat. ${ }^{1,4,5}$ Mastoidektomi revisi biasanya lebih sulit dari operasi pertama, karena anatomi dari telinga tengah bisa tidak jelas landmark bisa hilang dan struktur yang berbahaya sudah terpapar. ${ }^{1,4}$

\section{LAPORAN KASUS}

Seorang pasien laki-laki, berumur 25 tahun, datang ke poliklinik THT-KL pada tanggal 15 Juni 2011, dengan keluhan: telinga kanan berair sejak kecil, warna cairan kekuningan dan berbau, cairan yang keluar hilang timbul terutama bila batuk pilek. Riwayat operasi telinga kanan 2 tahun yang lalu di rumah sakit daerah. Telinga yang dioperasi ini tidak 
berair selama 2 bulan setelah operasi, setelah itu kembali berair. Pasien sudah berobat tetapi tidak sembuh. Pendengaran telinga kanan menurun, tidak ada sakit kepala hebat, tidak ada pusing berputar, tidak ada muntah proyektil, tidak ada wajah mencong.

Pada pemeriksaan fisik status generalis, keadaan umum sedang, tekanan darah 120/70 mmHg, nadi $80 x /$ menit, suhu afebris. Pada pemeriksaan regio mastoid kanan tampak sikatrik bekas insisi operasi, pada aurikula dekstra (AD), liang telinga lapang, sekret mukopurulen berwarna kekuningan, membran timpani perforasi atik. Pada aurikula sinistra (AS), liang telinga lapang, tidak ada sekret, membran timpani utuh dan reflek cahaya positif. Pada pemeriksaan hidung yaitu rinoskopi anterior dan rinoskopi posterior dalam batas normal. Tenggorok dalam batas normal. Pada test penala didapatkan kesan tuli konduktif pada telinga kanan (Tabel 1). Pasien didiagnosis dengan Otitis Media Supuratif Kronik (OMSK) tipe bahaya. Dilakukan pengambilan sekret liang telinga untuk kultur dan tes sensitifitas. Diberikan terapi siprofloksasin 2x500 mg, H2O2 3\% 2x5 tetes dan ofloksasin $3 \% 2 \times 5$ tetes di telinga kanan.

Tabel 1. Tes penala didapatkan tuli konduktif di telinga kanan.

\begin{tabular}{lll}
\hline & Kanan & Kiri \\
\hline Rinne & $(-)$ & $(+)$ \\
Weber & Lateralisasi ke kanan & \\
Swabach & memanjang & $\begin{array}{l}\text { Sama dengan } \\
\text { pemeriksa }\end{array}$ \\
\hline
\end{tabular}

Rontgen Mastoid posisi Schuller pasien sebelum operasi pertama yaitu tanggal 18 September 2009 di rumah sakit daerah, memperlihatkan air cell mastoid sklerotik (Gambar 1).

Pada rontgen mastoid posisi Schuller 2 tahun setelah operasi yaitu tanggal 25 April 2011, didapatkan pada telinga kanan terlihat air cell mastoid sklerotik dan terlihat destruksi tulang mastoid, kemungkinan bekas operasi pertama (Gambar 2).

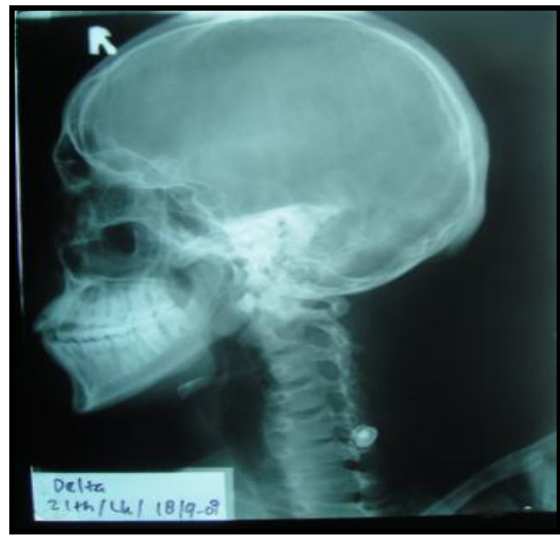

Gambar 1. Rontgen mastoid posisi Schuller sebelum operasi pertama 18/9/2009.

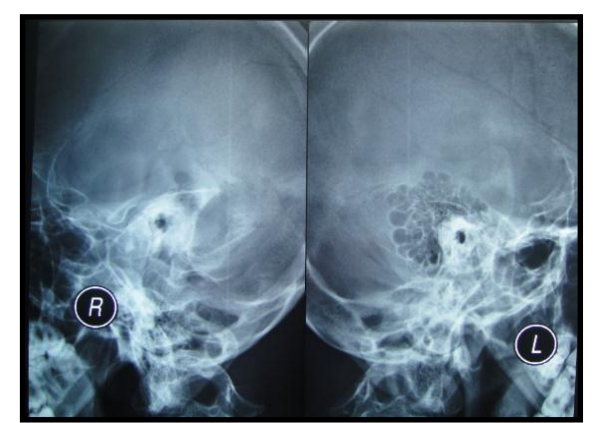

Gambar 2. Rontgen mastoid posisi Schuller setelah operasi pertama 25/4/2011.

Pada pemeriksaan Computer Tomografi Scanning (CT Scan) mastoid didapatkan hasil pneumatisasi air cell mastoid kanan tampak sangat berkurang dengan gambaran perselubungan pada mastoid kanan, tampak destruksi tulang mastoid kanan dan sklerotik, tidak tampak abses. Mastoid kiri baik. Kesannya mastoiditis aurikula dekstra (AD) dengan kolesteatom (Gambar 3 dan 4).

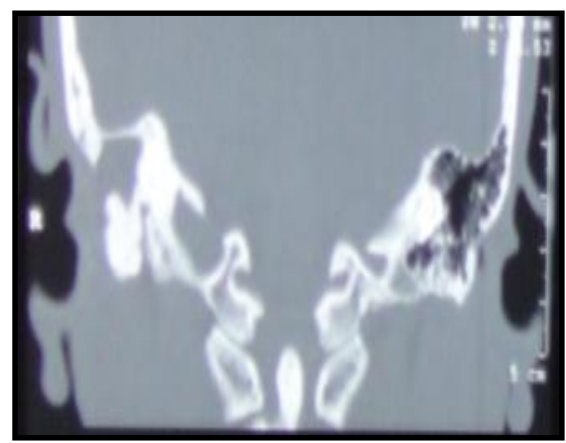

Gambar 3. CT Scan mastoid potongan koronal. Kesan destruksi tulang mastoid, mastoiditis dan kolesteatom. 


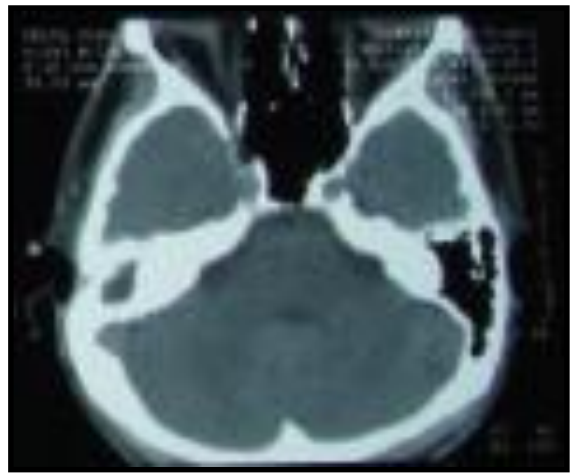

Gambar 4. CT Scan mastoid potongan aksial.

Pasien didiagnosis dengan OMSK AD tipe bahaya dan dipersiapkan untuk timpani-mastoidektomi dinding runtuh. Hasil pemeriksaan laboratorium darah, $\mathrm{Hb} 15 \mathrm{gr} / \mathrm{dl}$, leukosit 5600/mm3, hematokrit 47\%, trombosit 295.000/mm3, PT 11,5 detik, APTT 41,5 detik. Pada hasil pemeriksaan audiometri didapatkan tuli konduktif derajat sedang-berat di telinga kanan dengan ambang dengar 61,25 dB (Gambar 5).

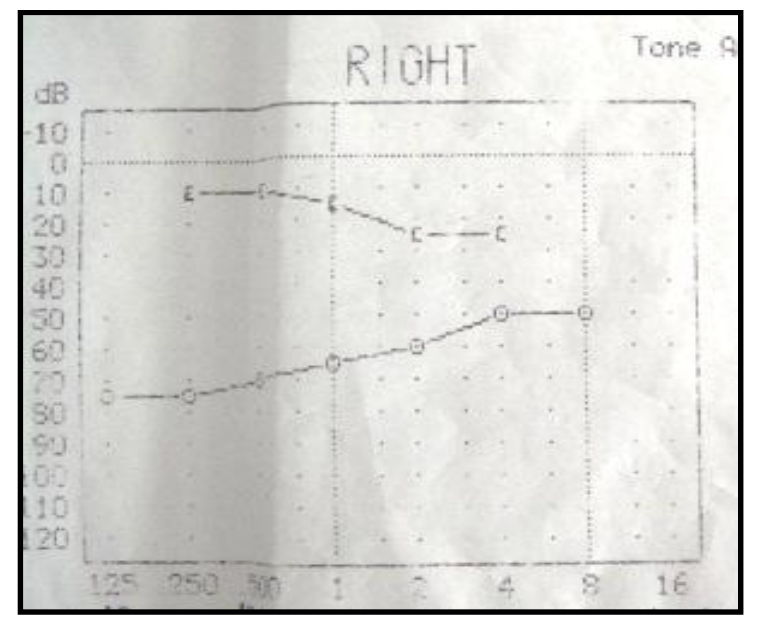

Gambar 5. Hasil audiometri sebelum operasi didapatkan tuli konduktif sedang berat dengan ambang dengan $61,25 \mathrm{~dB}$.

Operasi dilakukan pada tanggal 20 Juni 2011, dengan prosedur operasi, pasien di meja operasi posisi supine dalam anestesi umum dengan kepala miring ke kiri. Dilakukan tindakan septik antiseptik di lapangan operasi. Liang telinga kanan dievaluasi dengan mikroskop, tampak membran timpani perforasi atik, ditemukan sekret mukopurulen, dibersihkan dengan $\mathrm{H} 2 \mathrm{O} 2$ 3\% dan Povidone lodine. Selanjutnya dilakukan penandaan insisi $3 \mathrm{~mm}$ retroaurikular. Dilakukan infiltrasi dengan epinefrin 1:200.000 di regio retroaurikula. Dilakukan insisi tegak lurus terhadap kulit dan tangensial terhadap liang telinga. Dilakukan pengambilan graft dari fasia temporalis profunda. Insisi kulit diperdalam sampai terlihat korteks mastoid, dibuat insisi $\mathrm{T}$ untuk meluaskan lapangan operasi, dipasang retraktor, tampak tulang mastoid destruksi atau karena operasi sebelumnya dan terlihat kolesteatom. Dilakukan pengeboran, tampak kolesteatom memenuhi antrum, semua kolesteatom dibersihkan. Facial ridge direndahkan. sinodural angle dibersihkan. Didapatkan tegmen intak, sinus sigmoid intak, kanalis semisirkularis intak dan kanalis fasialis intak. Dinding posterior liang telinga diruntuhkan, korda timpani intak, tampak kolesteatom di kavum timpani dan tulang pendengaran telah hancur dan semua kolesteatom dibersihkan. Graft diletakkan membentang diatas kavum timpani dan difiksasi dengan spongostan. Dilakukan meatoplasti dengan membuang sebagian kartilago konka, sehingga liang telinga sangat lapang menyesuaikan dengan dinding posterior liang telinga yang diruntuhkan. Dilakukan obliterasi kavitas operasi dengan menggunakan flap jaringan lunak sekitar lapangan operasi dan luka operasi dijahit lapis demi lapis. Setelah operasi diberikan terapi injeksi seftriakson 2x1 gram, injeksi deksametason $3 \times 5 \mathrm{mg}$, pseudoefedrin $120 \mathrm{mg}+$ loratadin $5 \mathrm{mg} 2 \times 1$ kapsul, Ambroksol $3 \times 30 \mathrm{mg}$, drip tramadol dalam infus ringer laktat.

\section{Follow up hari pertama pasca operasi}

Anamnesis didapatkan, pasien tidak demam, tidak ada sakit kepala, tidak ada pusing berputar, tidak ada wajah mencong, nyeri pada lapangan operasi. Telinga kanan tertutup perban, tidak ada darah merembes dan tidak bau. Hidung dan tenggorok dalam batas normal. Diagnosis post timpanomastoidektomi dinding runtuh AD hari pertama atas indikasi OMSK AD tipe bahaya. Diberikan terapi injeksi seftriakson 2x1 gram, injeksi deksametason $3 \times 5 \mathrm{mg}$, pseudoefedrin $120 \mathrm{mg}+$ loratadin $5 \mathrm{mg} 2 \times 1$ kapsul, Ambroksol $3 \times 30 \mathrm{mg}$, drip tramadol dalam ringer laktat $3 \times 1$ ampul.

\section{Follow up hari ke-3 pasca operasi}

Dari anamnesis didapatkan, pasien tidak demam, tidak ada sakit kepala, tidak ada pusing 
berputar, tidak ada wajah mencong dan nyeri lapangan operasi berkurang. Pada telinga kanan terpasang tampon sofratul, tidak ada darah merembes dan tidak bau. Pada regio retro aurikula dekstra, luka operasi tenang dan tidak ada pus. Hidung dan tenggorok dalam batas normal. Diagnosis post timpanomastoidektomi dinding runtuh $A D$ hari ke-3 dan dilakukan ganti perban luar.

Hasil kultur sekret telinga didapatkan kuman Pseudomonas spp, yang sensitif terhadap gentamisin, siprofloksasin, ceftazidim, netilmisin dan cefoperazon. Terapi pasien diganti sesuai kultur yaitu injeksi seftazidime $2 \times 1$ gram, injeksi deksametason $3 \times 5 \mathrm{mg}$, pseudoefedrin $120 \mathrm{mg}$ + loratadin 5mg 2x1 kapsul, ambroksol $3 \times 30 \mathrm{mg}$, ofloxasin tetes telinga $2 \times 5$ tetes $\mathrm{AD}$, drip tramadol diganti asam mefenamat $3 \times 500 \mathrm{mg}$.

\section{Follow up hari ke-5 pasca operasi}

Anamnesis didapatkan tidak ada demam, tidak ada sakit kepala, tidak ada wajah mencong, tidak ada pusing berputar dan nyeri lapangan operasi minimal. Liang telinga kanan tertutup tampon sofratul, tidak ada darah merembes, tidak bau, Regio Aurikula dekstra luka bekas insisi tenang dan tidak ada pus. Hidung dan tenggorok dalam batas normal. Diagnosis post timpano-mastoidektomi dinding runtuh $A D$ hari ke-5. Dilakukan ganti perban luar, jahitan retroaurikula $A D$ dibuka selang seling, dan luka operasi tenang. Diberikan terapi injeksi seftazidime $2 \times 1$ gram, injeksi deksametason $3 \times 5 \mathrm{mg}$, ofloxasin tetes telinga $2 \times 5$ tetes AD pseudoefedrin $120 \mathrm{mg}$ + loratadin $5 \mathrm{mg} 2 \times 1$ kapsul, ambroksol 3×30 mg, asam mefenamat 3×500 mg bila nyeri.

\section{Follow up hari ke-7 pasca operasi}

Dari anamnesis didapatkan tidak ada demam, tidak ada sakit kepala, tidak ada wajah mencong, tidak ada pusing berputar dan nyeri lapangan operasi minimal. Pada liang telinga kanan tertutup tampon sofratul, tidak ada darah merembes dan tidak bau. Luka bekas insisi tenang. Hidung dan tenggorok dalam batas normal. Diagnosis post timpanomastoidektomi dinding runtuh $A D$ hari ke-7. Dilakukan ganti perban, jahitan retroaurikula dibuka semuanya dan luka operasi tenang. Pasien boleh pulang. Terapi siprofloksasin $2 \times 500 \mathrm{mg}$, ofloxasin tetes telinga $2 \times 5$ tetes $A D$, asam mefenamat bila nyeri. Pasien dianjurkan kontrol ke poliklinik THT 3 hari setelah pulang.

\section{Kontrol pasca operasi hari ke-14}

Dari anamnesis didapatkan, tidak ada telinga berair, tidak ada demam, tidak ada batuk, tidak ada pilek, tidak ada cairan keluar dari telinga. Pada $A D$ setelah dibuka tampon dalam didapatkan liang telinga sangat lapang, tidak ada sekret, debris ada, graft masih sukar dinilai. Hidung dan tenggorok dalam batas normal. Pada pasien ini dilakukan tes penala dan didapatkan hasil, tuli konduktif di telinga kanan. Hasil tes penala (Tabel 2). Diagnosis post timpanomastoidektomi dinding runtuh $A D$ hari ke-14. Diberikan terapi siprofloksasin $2 \times 500 \mathrm{mg}$, ofloxasin tetes telinga $2 \times 5$ tetes AD.

Tabel 2. Tes penala pasien post operasi hari ke-14, kesan tuli konduktif di telinga kanan

\begin{tabular}{lll}
\hline & kanan & kiri \\
\hline Rinne & $(-)$ & $(+)$ \\
Weber & $\begin{array}{l}\text { Lateralisasi } \\
\text { kanan }\end{array}$ & \\
Swabach & memanjang & $\begin{array}{l}\text { Sama dengan } \\
\text { pemeriksa }\end{array}$ \\
\hline
\end{tabular}

\section{Kontrol hari ke-24 pasca operasi}

Dari anamnesis didapatkan tidak ada telinga berair, tidak ada demam, tidak ada batuk, tidak ada pilek, tidak ada cairan keluar dari telinga. Pada pemeriksaan THT telinga kanan, didapatkan liang telinga sangat lapang, tidak ada sekret, ada debris, graft tampak tumbuh. Telinga kiri, hidung dan tenggorok dalam batas normal. Pada tes penala didapatkan tuli konduktif di telinga kanan (Tabel 3). Diagnosis post timpanomastoidektomi AD hari ke-24. Diberikan terapi ofloksasin tetes telinga $2 \times 5$ tetes $A D$. 
Tabel 3. Tes penala pasien post operasi hari kedua puluh empat, kesan tuli konduktif di telinga kanan.

\begin{tabular}{lll}
\hline & kanan & kiri \\
\hline Rinne & $(-)$ & $(+)$ \\
Weber & $\begin{array}{l}\text { Lateralisasi } \\
\text { ke kanan }\end{array}$ & \\
Schwabach & memanjang & $\begin{array}{l}\text { Sama dengan } \\
\text { pemeriksa }\end{array}$ \\
\hline
\end{tabular}

Hasil pemeriksaan histopatologi didapatkan, gambaran mikroskopis tampak potongan epitel berlapis gepeng, dengan massa keratin, debris dan nekrotik, gambaran sesuai dengan kolesteatom (Gambar 6).

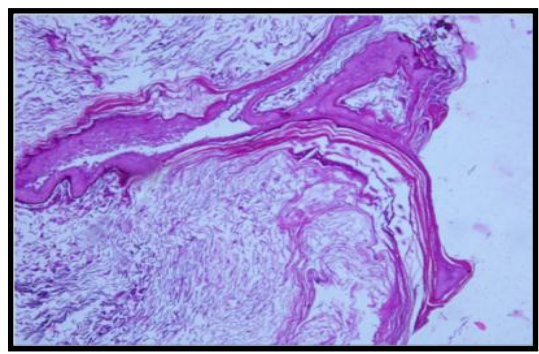

Gambar 6. Gambaran histopatologi sesuai dengan kolesteatom.

Kemudian pasien meminta untuk kembali ke Jakarta, karena harus masuk kembali bekerja dan kontrol ke rumah sakit di Jakarta. Pada pasien ini dilakukan pemeriksaan audiometri ulang, didapatkan perbaikan ambang dengar yaitu tuli konduktif telinga kanan derajat sedang, dengan ambang dengar 46, 25 dB (Gambar 7)

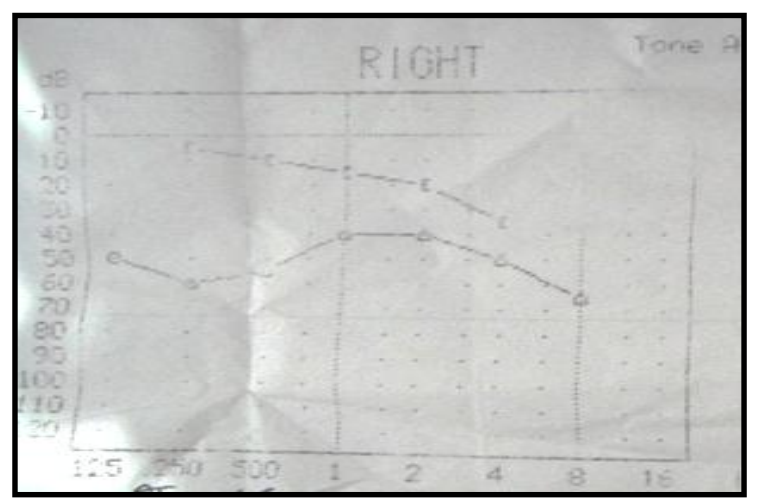

Gambar 7. Audiometri setelah operasi, dengan hasil tuli konduktif sedang berat $46,25 \mathrm{~dB}$.

\section{DISKUSI}

Pasien datang ke poli THT Dr. M.Djamil Padang dengan keluhan telinga kanan masih berair, dengan riwayat pasien sudah pernah operasi telinga 2 tahun yang lalu di rumah sakit daerah, tidak berair selama 2 bulan, setelah itu berair lagi. Pasien sudah berobat, tetapi masih tetap berair. Pada penelitian Cho et al tahun 1997-2004, mendapatkan keluhan terbanyak dari operasi mastoid yang membutuhkan mastoidektomi revisi adalah telinga berair yaitu $72,6 \% .^{8}$

Pada pasien ini telah dilakukan pemeriksaan penunjang yaitu rontgen mastoid posisi Schuller, terdapat gambaran berkurangnya pneumatisasi di telinga kanan. Rontgen mastoid posisi Schuller merupakan pemeriksaan standard untuk menilai mastoid, disini dapat dilihat luasnya pneumatisasi sel mastoid, lempeng tegmen, lempeng sinus dan daerah epitimpanum. ${ }^{7,8}$

CT Scan mastoid pasien ini memperlihatkan gambaran kolesteatom dan destruksi tulang. Pemeriksaan penunjang ini penting, meski bukan suatu keharusan, terutama dengan kecurigaan adanya kolesteatom. Kelebihan CT scan mastoid adalah dapat memperlihatkan lebih jelas ada atau tidaknya erosi/destruksi dinding lateral atik, erosi aditus ad antrum, erosi osikel, fistula labirin dan erosi tegmen timpani. ${ }^{4,8}$

Penyebab tersering kegagalan operasi adalah 1. facial ridge yang tinggi, 2. Meatoplasti yang tidak adekuat dan 3. Tulang yang bergaung. Skema penyebab tersering dari kegagalan operasi mastoid 4 (Gambar 8). Operasi mastoid yang adekuat diharapkan akan mengurangi kekambuhan akibat adanya kolesteatom, operasi membutuhkan peralatan, operator yang terlatih dan kepatuhan pasien dalam kontrol setelah operasi. ${ }^{4,9}$

Pasien ini di rumah sakit daerah dilakukan operasi simple mastoidectomy, karena waktu itu hanya ditemukan jaringan granulasi. Atallah melaporkan angka kejadian timbulnya kolesteatom setelah operasi mastoid adalah 7,6\%-57\%. ${ }^{1}$ Menurut Faramarzi et al pada pasiennya yang dilakukan operasi mastoidektomi revisi pada tahun 2004-2006, dari 116 telinga, kolesteatom ditemukan pada 71 telinga $(61,20 \%) .{ }^{10}$ 


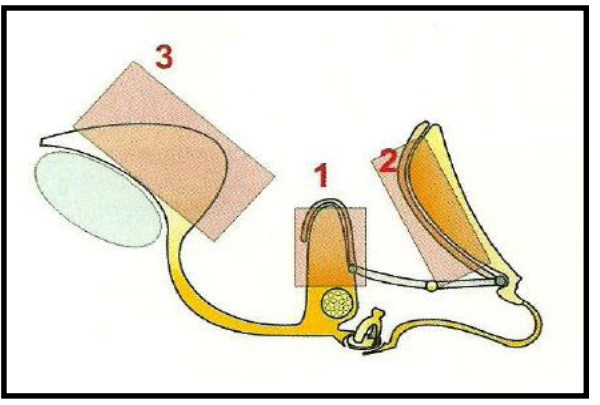

Gambar 8. Skema penyebab tersering kegagalan operasi adalah 1 . facial ridge yang tinggi, 2 . Meatoplasti yang tidak adekuat, dan 3 . Tulang yang bergaung. ${ }^{4}$

Kolesteatom terbentuk karena proses invaginasi dari membran timpani pars flaksida karena adanya tekanan negatif di telinga tengah. ${ }^{11,12}$ Meruntuhkan dinding posterior liang telinga adalah pilihan untuk kasus dengan adanya kolesteatom. Tujuan meruntuhkan dinding posterior dari liang telinga adalah eradikasi total dari kolesteatom. ${ }^{2}$

Pada pasien ini kolesteatom ditemukan pada antrum mastoid. Pada penelitian Faramarzi et al kolesteatom ditemukan terbanyak pada sinodural angle $(28,28 \%)$, di atik(23\%), tip mastoid $(13 \%)$ dan di hipotimpani(5\%). ${ }^{10}$ Menurut penelitian Bercin et al ${ }^{12}$ pada tahun 2005-2008 mendapat-kan kegagalan operasi pada mastoidektomi dinding runtuh adalah kolesteatom dan meatoplasti yang tidak adekuat pada $80,9 \%$ kasus, air cell di sinodural angle dan resesus supra tuba yang tertutup pada $71,4 \%$ kasus, facial ridge yang tinggi, air cell yang tidak bersih di apex mastoid pada $52,4 \%$ kasus.

Pada pasien ini juga ditemukan facial ridge yang tinggi, facial ridge yang tinggi dikenal sebagai "beginner hump". Hal ini dapat menyebabkan higiene lokal yang tidak baik, merupakan obstruksi mekanik, menyebabkan akumulasi debris, dan juga mencegah hubungan antara kavum mastoid dan telinga tengah. ${ }^{10,13,14}$

Pada pasien ini dilakukan mastoidektomi revisi, dengan landmarks operasi yang sudah tidak jelas. Mastoidektomi revisi lebih banyak komplikasi dan lebih beresiko dibandingkan operasi pertama. ${ }^{13}$ Perlu untuk membersihkan semua kelainan pada air cell, merendahkan facial ridge, dinding lateral epitimpani, perhatian khusus pada tip mastoid, sinodural angle, sel tegmental dan hipotimpanum. Kecenderungan untuk terkena saraf fasialis adalah besar, tetapi ini dapat dikurangi dengan penggunaan mikroskop yang baik dan keahlian dari operator. ${ }^{14}$

Pada pasien ini dilakukan meatoplasti. Penyebab mekanik yang mengakibatkan tertahannya debris pada $23 \%$ kasus adalah meatoplasti yang tidak adekuat. Meatoplasti dapat dikerjakan dengan teknik membuang kartilago konka, atau dibuat insisi vertikal pada celah antara rim heliks anterior dan tragus menuju ke liang telinga dan dilebarkan, ini menyesuaikan dengan bentuk tulang yang dinding posterior liang telinga yang diruntuhkan. $5,9,10$

Pada pasien ini meatoplasti dilakukan dengan membuat insisi dan membuang kartilago konka, menyesuaikan dengan dinding posterior liang telinga yang diruntuhkan. Teknik lain untuk mendapatkan meatoplasti yang adekuat adalah endaural meatoplasti, Z plasti dan $Y$ plasti. 5,15,16

Pada pasien ini juga dilakukan obliterasi kavitas operasi yaitu dengan flap jaringan sekitar operasi. Beberapa ahli menganjurkan obliterasi kavitas operasi dengan menggunakan kartilago, graft dari lemak perut dan jaringan lunak lokal. ${ }^{13}$ Strategi mastoidektomi revisi adalah, identifikasi nervus fasialis, membuang tulang yang bergaung, menipiskan tulang yang menutupi sinus sigmoid, memperluas sinodural angle, merendahkan facial ridge, membuang anterior/posterior buttress dan membuat meatoplasti yang adekuat. ${ }^{2,4}$

Kegagalan operasi pertama pasien ini kemungkinan tidak bersihnya seluruh jaringan patologis, atau karena ditemukan ada tulang yang bergaung, yang menyebabkan sulitnya drainase juga kemungkinan terlambat kontrol pasca operasi pertama. Setelah operasi kedua, pada pasien ini secara subjektif ada perbaikan pendengaran setelah operasi, dari pemeriksaan audiometri didapatkan peningkatan ambang dengar $15 \mathrm{~dB}$, padahal tulang pendengaran sudah hancur, ini dimungkinkan karena adanya graft yang dibentangkan di kavum timpani. Penelitian Atallah et al didapatkan adanya peningkatan pendengaran secara subjektif pada $71 \%$ pasien. ${ }^{1}$ Setelah dilakukan operasi mastoid terutama dengan adanya kolesteatom, sangat penting perawatan setelah operasi. Idealnya pasien setelah operasi mastoid tetap kontrol selama bertahun-tahun., ${ }^{4,17}$ 


\section{DAFTAR PUSTAKA}

1. Atallah SM, Al Anazy F, Al Dousary S. Surgical findings in revision radical mastoidectomy. Bahrain Medical Bulletin. 2010;32(4):1-4.

2. Ajalloueyan M. Modified radical mastoidectomy techniques to decrease failure. Medical Journal of the Islamic Republic of Iran. 1999;13(3):179-83.

3. Telian SA, Cecelia, Scmalbach E. Cronic otitis media. Dalam: Ballenger's Otorhinolaryngology Head and Neck Surgery. Ontario: BC Decker Inc; 2003. hlm.261-91.

4. Djaafar ZA, Helmi, Restuti RD. Kelainan telinga tengah. Dalam: Buku Ajar IImu Kesehatan THT, Edisi ke-6. Jakarta:FKUI; 2007. hlm.64-74.

5. Chole RA, Brodie HA, Jacob A. Surgery of mastoid and Petrosa. Dalam: Byron JB. Head \& Neck surgery Otolaryngology. Philadelphia: Lippincott Williams \& Wilkins; 2006. hlm. 2093-4.

6. Sanna M, Sunose H, Mancini F, Russo A, Taibah A. Revision surgey after open technique. Dalam: Middle Ear And Mastoid Microsurgery. New York: Thieme; 2009. hlm.324-32.

7. Patil S, Ahmed J, Patel N. Endaural meatoplasty: the whipps cross technique. The Journal of Laryngology \& Otology. 2011;125:78-81.

8. Cho YS, Hong SD, Chung KW, Hong SH, Chung $\mathrm{WH}$, Park SH. Revision surgery for chronic otitis media: and outcomes in comparison with primary surgery. Auris Nasus Larynx. 2010;13(3):179-83.
9. Helmi. Otitis media supuratif kronis. Jakarta: Balai Penerbit FKUI; 2005.

10. Faramarzi A, Zarandi MM, Khorsandi MT. Intraoperative findings in chronic otitis media Surgery. 2008; 11(2):196-9.

11. Raynov AM, Choung YH, Park HY, Choi SJ. Establishment and characterization of an in vitro model of cholesteatoma. Clinical and experimental otorhinolaryngology. 2008;1:86-91.

12. Bercin M, Kutluhan A, Bozdemir K, Yalciner G, Sari $\mathrm{N}$,Karamese $\mathrm{O}$. Results of revision mastoidectomy. Acta Oto-Laryngologica. 2009;129:138-41.

13. Salami A, Mora R, Dellepiane, Crippa B, Guastini L. Result of revision mastoidectomy with Piezosurgery. Acta oto-laryngologica. 2010;130: 1119-24.

14. Martin MS, Raz Y. Mastoid surgey. Springer. 2008: 50-9.

15. Murray DP, Jassar P, Lee MS. Z meatoplasty technique in endaural approach mastoidectomy. The journal of laryngology \& otology. 2000;114: 526-7.

16. Suskind DL, Bigelow CD, Knox GW. Y modification of meatoplasty. Otolaryngol Head Neck surgery. 2009;121:126-7.

17. Kim MY, Yeo SG. Long term clinical efficacy of lokal care of post surgical lokalized cholesteatomas. Journal Of Medical Science Research. 2007;2:43-8. 